\title{
アルミナ強化磁器素地の強度とワイブル分布
}

\author{
小林雄一・大平修・大橋康男 - 加藤 悦 朗*

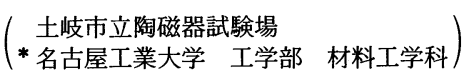

\section{Strength and Weibull Distribution of Alumina Strengthened Whiteware Bodies}

\author{
Yuichi KOBAYASHI, Osamu OHIRA, Yasuo OHASHI and Etsuro KATO* \\ $\left(\begin{array}{l}\text { Toki Municipal Institute of Ceramics } \\ \text { 1556-2, Dachi-cho, Toki-shi } 509-54 \\ \text { * Nagoya Institute of Technology }\end{array}\right)$
}

A whiteware body composition containing $30 \%$ alumina was investigated to study the effects of milling and sieving raw materials on bending strength and Weibull distribution of fired bodies. Test bars were formed by slip casting into a rectangular shape $(10 \mathrm{~b} \times 5 \mathrm{~b} \times 70 \mathrm{~mm})$ and fired at $1350^{\circ} \mathrm{C}$ for $1 \mathrm{~h}$ in a reducing atmosphere. Mean bending strength of the fired specimens increased with milling time, almost proportionally to time. Weibull modulus, however, decreased with milling time, because of a small amount of coarse grains which remained in the slip even after long milling. Removing the coarse grains in the slip through a finer sieve resulted in increased strength and higher Weibull modulus. It was found that quartz grains included in the raw feldspar were more effective as fracture sources than feldspar itself. A mean bending strength of $240 \mathrm{MPa}$ and Weibull modulus of 21 were obtained from the slip milled for $24 \mathrm{~h}$ and sieved through 350 mesh.

[Received January 13, 1987 ; Accepted April 21, 1987]

Key-words : Whiteware bodies, Alumina addition, Bending strength, Weibull distribution, Maximum grain size, Sieving

\section{1. 緒 言}

現在東濃地方で大量に生産されている日常食器等の一 般磁器製品は，ケイ石一長石-粘土系の素地がほとんどで ある. 著者らが長年にわたり多数の磁器素地試料に対し 測定した結果では，無釉素地の曲げ強度は多くは 60〜 $80 \mathrm{MPa}$ であり，最高值でも $120 \mathrm{MPa}$ を超えるものは なかった. 最近食器の分野でも，機械洗浄による「ふち がけ」などの発生から強度向上の要望が高まり，ケイ石 成分をアルミナで置換した強化磁器が学校やホテルの食 堂用に生産され始めている.

このアルミナ強化磁器については, 既に 1946 年,

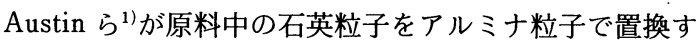
ることにより高強度化できることを発表して以来, 電磁 器あるいは食器の強度向上を目的とする多数の研究が行

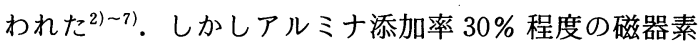
地では, 曲げ強度 $200 \mathrm{MPa}$ 以上のものはないようであ る. またこのような磁器素地に対してワイブル係数を加 味して検討した報告も見当たらない.

本報では, 原料コスト, 坏土の成形性等, 食器として 通常の工業生産に完全に適合できるアルミナ添加率 $30 \%$ の配合素地を用い, 統計的手法で製造工程を検討 した結果，長石質原料からの極めてわずかな粗粒子の混 在が焼成後の磁器素地の強度を劣化させていることを見
だしこれを除くことにより $240 \mathrm{MPa}$ 以上の高強度磁 器素地をワイブル係数 20 以上で製造することが可能と なったので報告する．

\section{2. 実験方法}

\section{1 原料及び試験片の作製}

用いた原料の化学分析値を表 1 に示す. 蛙目粘土は力 オリナイトを主として, X 線回折の結果約 $3 \%$ の石英微 粒子を含んでいる. N.Z. チャイナクレーはハロイサイト を主成分とし, X 線回折の結果及びノルム計算から, 石 英とクリストバライトの微粒子を合計で約 $7 \%$ 含んで

Table 1. Chemical composition of raw materials.

\begin{tabular}{|c|c|c|c|c|}
\hline & $\begin{array}{c}\text { Ohira } \\
\text { Feldspar }\end{array}$ & $\begin{array}{l}\text { Gairome } \\
\text { clay }\end{array}$ & $\begin{array}{l}\text { N.Z.China } \\
\text { clay }\end{array}$ & Alumina \\
\hline $\mathrm{SiO} 2$ & 66.56 & 48.30 & 49.78 & 0.012 \\
\hline $\mathrm{Al}_{2} \mathrm{O}_{3}$ & 1821 & 34.73 & 35.72 & 99.6 \\
\hline $\mathrm{Fe}_{2} \mathrm{O}_{3}$ & 0.06 & 1.24 & 0.26 & 0.010 \\
\hline $\mathrm{TiO}_{2}$ & 0.01 & 0.66 & 0.12 & \\
\hline $\mathrm{CaO}$ & 1.10 & 0.19 & tr. & \\
\hline $\mathrm{MgO}$ & 0.01 & 0.39 & tr. & \\
\hline $\mathrm{K}_{2} \mathrm{O}$ & 10.37 & 0.99 & tr. & \\
\hline $\mathrm{Na}_{2} \mathrm{O}$ & 3.50 & 0.25 & 0.06 & 0.35 \\
\hline Ig.loss & 0.22 & 12.82 & 14.05 & \\
\hline Total & 100.04 & 99.57 & 99.99 & \\
\hline $\begin{array}{c}\text { Blending } \\
\text { ratio }\end{array}$ & 30 & 10 & 30 & 30 \\
\hline
\end{tabular}


いる. いずれも $10 \mu \mathrm{m}$ を超える粗粒子を含有しない微 細な水籍物である.アルミナは日本軽金属製の汎用アル ミナA 32 で, 比表面積平均径は約 $0.4 \mu \mathrm{m}$ であるが, いくらか凝集し，粒度分析では平均粒子径が約 $1.5 \mu \mathrm{m}$ である. 長石質原料としては，現在工業的に製造されて いる市販の大平長石（風化花コウ岩の乾式脱鉄精製物） を用いた。これは純粋な長石ではなく，石英を約 $4 \%$ 含んでおり， $44 \mu \mathrm{m}$ 以下が約 $50 \%$ の粒度のものである. これらの原料を通常の工業生産プロセスに対応させて, $\alpha$-アルミナ $30 \%$ ，長石質原料 $30 \%$ ，カオリン質原料 $40 \%$ の一般的な配合割合で $1 \mathrm{~kg}$ 調合し，内容積 $3 l$ の 磁製ポットとボールにより所定時間湿式ボールミル粉砕 した．この泥漿を，粗粒子を除去するためのふるいの目 開き径を変えふるいに通した後脱水し, 解膠剤として $0.15 \mathrm{wt} \%$ の水ガラスを加えて水分約 $27 \%$ の鋳込み用 泥漿とし, 真空脱泡後 $10 \times 5 \times 70 \mathrm{~mm}$ の角柱状試験片を 固形鋳込み成形した。試験片は十分乾燥の後ガス炬によ り $1000^{\circ} \mathrm{C}$ までは約 $200^{\circ} \mathrm{C} / \mathrm{h}$ で, $1000^{\circ} \mathrm{C}$ 以上は約 $100^{\circ} \mathrm{C} / \mathrm{h}$ の速度で $1350^{\circ} \mathrm{C}$ まで昇温し, 1 時間保持して から炬冷した。このとき $1000^{\circ} \mathrm{C}$ 以上では $\mathrm{CO}$ 濃度約 2 ～5\% の還元雾囲気とした.

\section{2 測 定}

湿式ボールミル粉砕後のふるい残査量は，泥漿をふる いに通し，軽く水洗，乾燥した後科量して求めた．原料 及び粉砕物の粒度分布は島津製作所製 RS-1000 を用い, 解膠剤としてピロリン酸ソーダを加え, 超音波洗浄器に より 10 分間以上分散処理後測定した. 真密度は, 試料 をアルミナ乳鉢で指頭に感じなくなる程度に粉砕し，ピ クノメーター法により測定した. かさ密度, 気孔率等は, 水中にて 3 時間煮沸した後水中重量等を測定し, そのと きの水の密度を考慮して計算した。測定值のばらつきは 真密度では $\pm 0.002 \mathrm{~g} / \mathrm{cm}^{3}$ 以内, かさ密度では 0.001 $\mathrm{g} / \mathrm{cm}^{3}$ 以内 (5 点測定值による) であった.

曲げ強度は米倉製作所製 CATY $2002 \mathrm{~S}$ 型万能試験機 により測定した．曲げ強度の分布をごのような関数で近 似するかについては種々議論)されているが，最も一般 的に用いられることの多い，2 変数ワイブル統計により 整理9)した．詳しい曲げ強度の測定方法については結果 及び考察の部分で述べる.

\section{3. 結果及び考察}

\section{1 曲げ強度の測定方法の検討}

曲げ強度の分布を知るためには測定数が多数必要とな るので, 時間を節約するために焼成後試験片を研磨加工 せずに直接曲げ強度測定を正確に行える方法について検 討した.

ここで試験片は鋳込み法により成形しているため, JISR 1601 などに規定されている程度の平行度は得られ
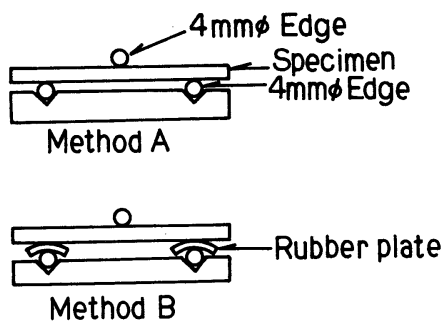

Fig. 1. Two methods for measurement of 3-point bending strength.

ず, 強度測定に際し試験片に均一に荷重が加わらない恐 れがある．そこで荷重台には鋼球を挟み，支持台側は図 1 に示すような二つの方法により予備試験を行った．A 方法は試験片を支持用ロールの上にそのまま静置する通 常の方法である，B 法では試験片と支持用ロールの間 に硬度 60 , 厚さ $3 \mathrm{~mm}$ の生ゴム製の板を挟み, 試験片 に均一に荷重が加わるようにした。焼成後の試験片の寸 法は約 $8.4 \times 4.2 \times 60 \mathrm{~mm}$ である. スパンは $30 \mathrm{~mm}$ とし, クロスヘッドスピードは $\mathrm{A}$ 法の場合は $0.5 \mathrm{~mm} / \mathrm{min}$ と した，B法の場合，ゴム板により変位が吸収され応力 負荷速度が小さくなるので $3 \mathrm{~mm} / \mathrm{min}$ とした。破断点 近くにおける応力負荷速度は，A，B 法共に約 3 $\mathrm{kg} / \mathrm{mm}^{2} / \mathrm{s}$ であった. 試験片は, 24 時間湿式ボールミル 粉砕した後目開き径 $44 \mu \mathrm{m}$ ( $350 \mathrm{mesh})$ 及び $32 \mu \mathrm{m}$ (425 mesh）のふるいに通した各泥漿から成形，焼成した。 焼成したままのもの，及び焼成物を＃1000 の研粒を用 い研磨仕上げした試験片約 40５0 本に対し曲げ強度を 測定した結果を図 2 に示す。なおワイブル係数は最小二 乗法により計算した．図 2 (a) から分かるように，350 mesh の試料を比較すると，A 法による通常の測定では 平均曲げ強度が $218 \mathrm{MPa}$, ワイブル係数が 13.7 で共に 小さく,これに対し B 法では平均曲げ強度が $243 \mathrm{MPa}$, ワイブル係数が 21.8 であった. B 法ではゴム板を使用 することにより明らかに平行度の不備をカバーできる が，平行度が良好な場合には面接触することによりスパ ンがいくらか短くなる可能性があり, 平行度が良くない 場合には支持中心が試験片の対角線方向にずれ，結果的 にスパンが長くなる可能性もある。したがって測定結果 へのこれらの影響を検討する目的で，425 mesh の試料 について研磨した試験片を $\mathrm{A}$ 法で, 研磨しない試験片 を B 法で測定した，その結果，図 2 (b) のように両者 はかなり良い一致を示した，研磨した試験片と焼成した ままの試験片では, 試料の表面状態も異なるので, 個々 の試験片に対しては同一の条件での測定とは言えない が，強度分布の測定結果の良い一致から，統計的にはほ ぼ同一の破壊源に起因する破壊を測定したことになると 考えることができる. 以後の曲げ強度の測定結果は $\mathrm{B}$ 法により行ったものである. 


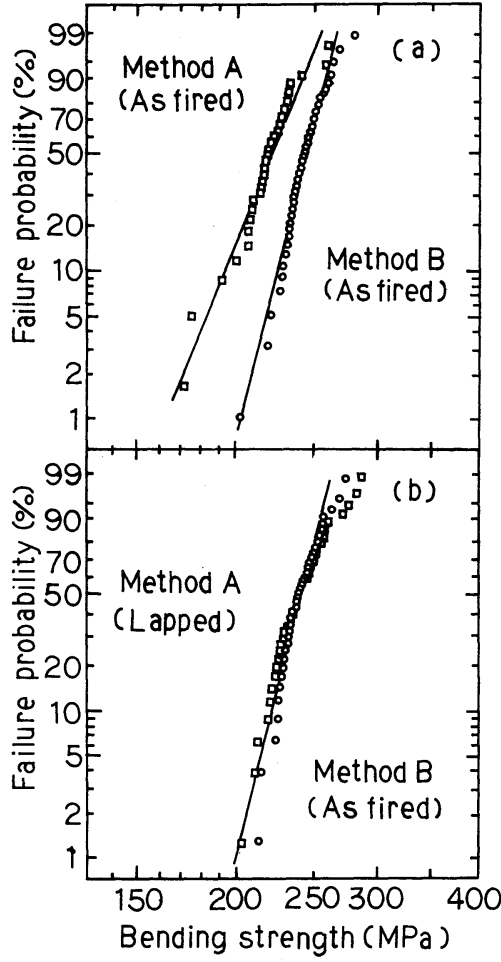

Fig. 2. Comparison of Weibull plots for strength measured by two methods. Specimens were obtainted from slips milled for $24 \mathrm{~h}$ and passed through (a) 350 mesh and (b) 425 mesh.

\section{2 粉砕時間の影響}

粒度と曲げ強度の関係について調べるために, 湿式 ボールミル粉砕の時間を $6,12,18,24 \mathrm{~h}$ と変え, それ ぞれ目開き径 $63 \mu \mathrm{m}$ (250 mesh) のふるいに通し, 鋳込 み成形後焼成して多数の試験体を得た.このときのふる い残査量を表 2 に, 粒度分布を図 3 に示す。この結果は 比重の異なる混合物を測定したものであるが, 長石質原 料以外はすべて微粒子原料を出発原料としているので, 変化は主に長石質原料の粒度分布の変化を示していると 考えてよい. 粉砕時間とともに粒度は細かくなり, それ に対応してふるい残査量も減少する. 残査は光学顥微鏡 観察の結果, 雲母（外形は雲母であるが, 風化のため一 部緑泥石に変質している) と長石及び少量の石英であり, いずれも長石質原料からのものである。また微量ではあ るがアルミナの 2 次粒子, 凝集体が短時間粉砕の場合に

Table 2. Amount of residue remained on 250 mesh sieve after milling.

\begin{tabular}{c|c}
\hline $\begin{array}{c}\text { Milling time } \\
\text { hour }\end{array}$ & $\begin{array}{c}\text { Residue (over } 63 \mu \mathrm{m}) \\
\text { ppm }\end{array}$ \\
\hline 6 & 1320 \\
12 & 121 \\
18 & 22 \\
24 & 14.6 \\
\hline
\end{tabular}

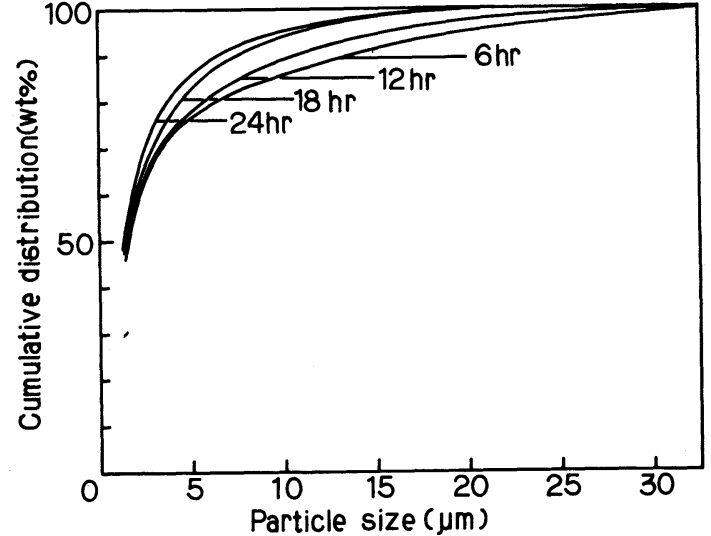

Fig. 3. Particle size distribution of milled materials.

認められた．粉砕時間の異なる泥漿から作製した各試験 片の焼成後の物理的性質を表 3 に示す. どの場合も相対 密度約 $99 \%$ に達しておりち密な焼成素地である. 真密 度は時間とともにわずかに小さくなる傾向が認められ， かさ密度もそれに伴って小さくなる．またX 線回折に よれば,焼成素地の構成相は,おおよそ $\alpha$-アルミナ $30 \%$ ， ムライト $12 \%$, 残りはガラス相であった。

Table 3. Physical properties of specimens fired at $1350^{\circ} \mathrm{C}$ for $1 \mathrm{~h}$.

\begin{tabular}{cccccc}
\hline $\begin{array}{c}\text { Milling } \\
\text { time } \\
(\mathrm{hr})\end{array}$ & $\begin{array}{c}\text { True } \\
\text { density } \\
\left(\mathrm{g} / \mathrm{cm}^{3}\right)\end{array}$ & $\begin{array}{c}\text { Bulk } \\
\text { density } \\
\left(\mathrm{g} / \mathrm{cm}^{3}\right)\end{array}$ & $\begin{array}{c}\text { Relative } \\
\text { density } \\
(\%)\end{array}$ & $\begin{array}{c}\text { Apparent } \\
\text { porosity } \\
(\%)\end{array}$ & $\begin{array}{c}\text { Total } \\
\text { porosity } \\
(\%)\end{array}$ \\
\hline 6 & 2.871 & 2.842 & 98.99 & 0.13 & 1.01 \\
12 & 2.869 & 2.836 & 98.85 & 0.06 & 1.15 \\
18 & 2.865 & 2.833 & 98.88 & 0.06 & 1.13 \\
24 & 2864 & 2.830 & 98.81 & 0.07 & 1.20 \\
\hline
\end{tabular}

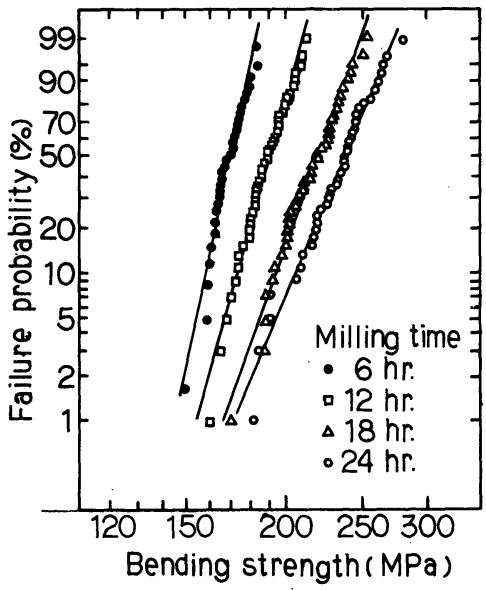

Fig. 4. Effect of milling time on Weibull distribution of fired bodies. Materials were passed through 250 mesh sieve. 


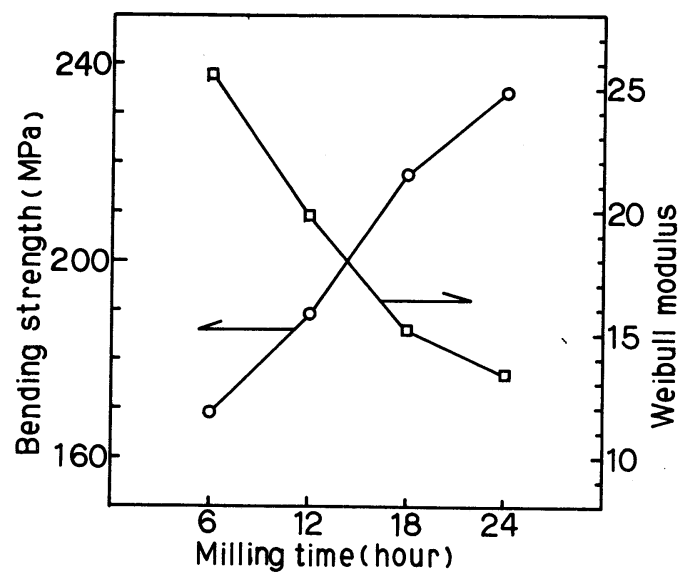

Fig. 5. Effect of milling time on bending strength and Weibull modulus.

粉砕時間を異にした各焼成素地の試験片に対する曲げ 強度の測定值の分布は図 4 に示すようである. 粉砕時間 とともに強度は増大することが明らかである。，一方ワイ ブル係数は図 5 に示すように減少する.このワイブル係 数の減少は, 粉砕時間の増大による高強度試料群の強度 増加が, 低強度試料群のそれより顕著であることによる ものである. セラミックスの強度の分布が flaw size の 分布に依存していることは多くの研究 ${ }^{100}$ の結果知られて いる. 本研究結果も曲げ強度が粒子径に依存しており, 粒界もしくは相境界が flaw size として作用し, 強度を 支配していると言ってょいであろう. 本研究においては 粉砕時間を長くすることにより微粒子部分を増大させ, ふるいを通すことにより粗粒子を残査として除去してい る. したがって, 最高強度の増大は粉砕時間の増大によ る焼成素地組織の微細化を示すものであり, また最低強 度の増加は粉砕時間の増大による素地中の粗粒子の含有 量の減少によってもたらされたものと考えられる.

\section{3 ふるい目開き径の影響}

ワイブル係数に影響する因子を更に明確にするため, 粉砕時間が $24 \mathrm{~h}$ の場合について, ふるいの目開き径を 変えて調製した泥墏からの試料の焼成素地に対し曲げ強 度及びその分布を測定した.この場合の焼成素地の平均 曲げ強度及びワイブル係数等を図 6 , 図 7 に示す. 平均 曲げ強度は目開き径が小さくなるに従って少しずつであ るが増大している. また目開き径が $63 \mu \mathrm{m}$ 以上の場合 ではワイブル係数はあまり変わらず, 12 から 13.5 の值 を示すが, $44 \mu \mathrm{m}$ 以下の場合には 20 以上の值を示す. このとき残査量は表 4 に示すように, 目開き径が小さく なると対数的に増えるが, わずか 50 140 ppm の粗粒 子を除くことによりワイブル係数は著しく増大すること が分かる.これらの結果は, 粉砕時間が $24 \mathrm{~h}$ の場合で は $44 \mu \mathrm{m}$ 以上の粒度分布が強度, 特に強度の分布を支

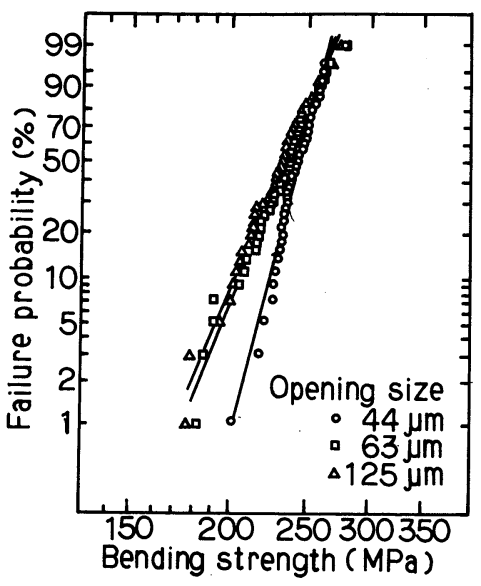

Fig.6. Effect of sieving for slip of raw materials milled for $24 \mathrm{~h}$ on Weibull distribution of fired bodies.

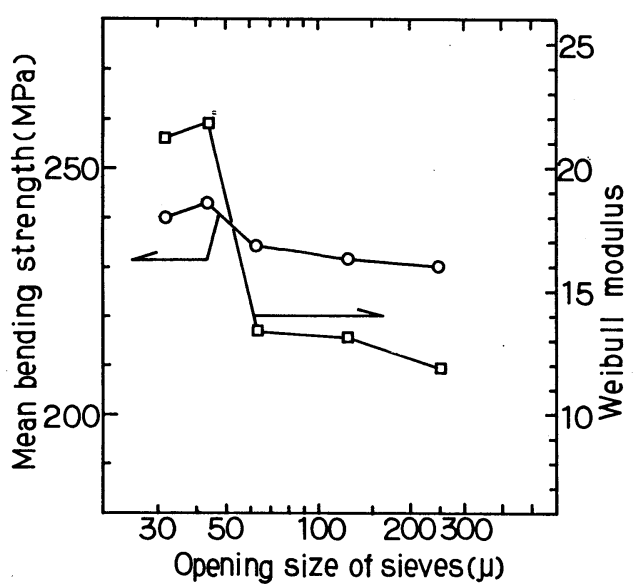

Fig.7. Effect of sieving for slip of raw materials milled for 24 th on Weibull modulus and bending strength of fired bodies.

Table 4. Amount of residue remained on sieves after milling for $24 \mathrm{~h}$.

\begin{tabular}{c|c}
\hline $\begin{array}{c}\text { Opening size } \\
\mu \mathrm{m}\end{array}$ & $\begin{array}{c}\text { Residue } \\
\mathrm{ppm}\end{array}$ \\
\hline 32 & 137 \\
44 & 43 \\
63 & 14.6 \\
125 & 2.0 \\
250 & 0.7 \\
\hline
\end{tabular}

配していることを示している．表 4 のふるい残査量は， 図 3 の粒度分布曲線では分からないほど微量含有されて いる粗粒領域の粒度分布曲線に相当する。したがってこ れと表 2 の粉砕時間によるふるい残査量の変化を比較す ると，粉砕時間の効果とふるい目開き径の効果を同一の 尺度で比較検討することができる．これをワイブルプ ロットの概念図とともに図8に示して考察を加える.

粉砕時間の変化に対し, 粒度分布は粗粒領域の狭い範 囲でほぼ平行に変化すると仮定すれば， 250 mesh ふる 

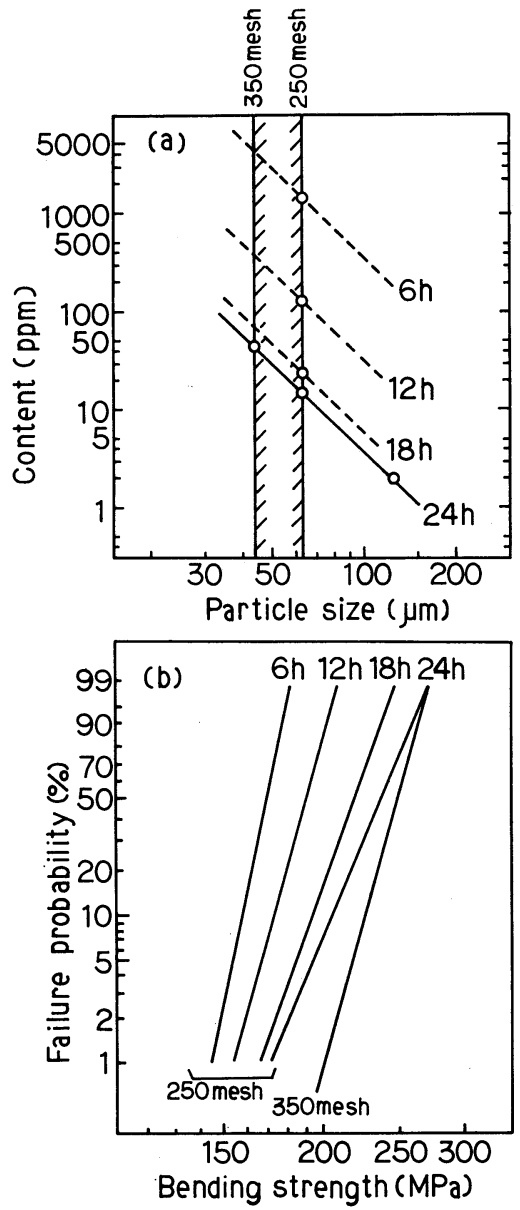

Fig. 8. Relation between coarse particle content and Weibull distribution of fired bodies.

い（目開き径 $63 \mu \mathrm{m}$ ) を通した泥漿中に含まれる $44 \mu \mathrm{m}$ 以上の粗粒子は粉砕時間とともに指数関数的に減少す る. いま焼成素地中に平均粒径 $r(\mu \mathrm{m})$ の球状粗粒子が $50 \mathrm{ppm}$ 均一に分布している場合, $1 \mathrm{~mm}^{3}$ 中に含まれる 粗粒子数 $N$ は, 密度をすべて同じと近似すれば,

$$
\begin{aligned}
N & =\frac{50 \times 10^{-6}}{\frac{4}{3} \pi\left(\frac{r}{2} \times 10^{-3}\right)^{3}} \\
& =9.5 \times 10^{4} \cdot \frac{1}{r^{3}} \quad\left[\text { 個 } / \mathrm{mm}^{3}\right]
\end{aligned}
$$

である. $r=45 \mu \mathrm{m}$ とすると $N=1.04$ 個 $/ \mathrm{mm}^{3}, r=60$ $\mu \mathrm{m}$ とすると $N=0.44$ 個 $/ \mathrm{mm}^{3}$ となる. 松尾と北上 ${ }^{11)}$ に よれば, ワイブル係数が大きくなるほど破壊位置は荷重 点淔下の狭い領域に制限されるとしており, その領域は 文献 11) における (13) 式を用いて図から読み取ると, ワ イブル係数が 20 以上の場合には最大応力の 0.9 倍以上 の応力が作用している部分である. 本研究における試験 体寸法（断面積約 $8 \times 4 \mathrm{~mm}^{2}$, スパン $30 \mathrm{~mm}$ ) において,

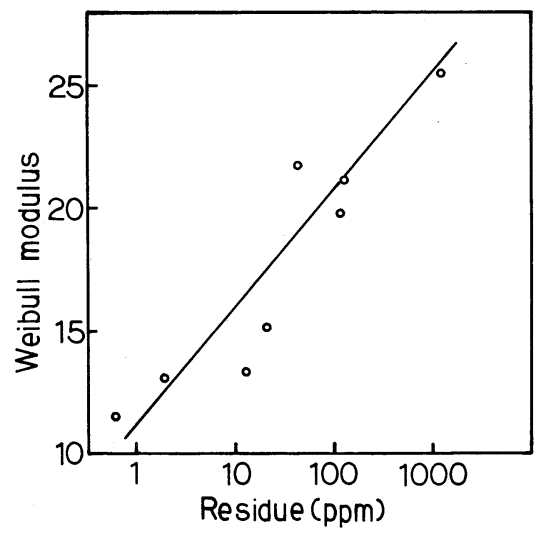

Fig. 9. Relation between amount of residue removed with sieve and Weibull modulus of fired bodies.

最大応力の 0.9 倍以上の応力が作用している部分の体積 は約 $8 \times 0.2 \times 3 \mathrm{~mm}^{3}=4.8 \mathrm{~mm}^{3}$ となり，ここに含まれる 粗粒子数は約 2 5 個となる.すなわち $50 \mathrm{ppm}$ 程度の 非常に少ない量でもすべての試験体の強度に影響を与え るに足りる量であることが分かる．粉砕時間の短い場合 には, $44 \mu \mathrm{m}$ 以上 $(44 \sim 63 \mu \mathrm{m})$ の粗粒子は $1000 \mathrm{ppm}$ を超え, 全試料の強度がこの影響を受けて弱くなり, ワ イブル係数はむしろ大きくなる. しかし粉砕時間が長く なるに従って，これは指数関数的に減少して $50 \mathrm{ppm}$ 以 下となり，この影響を全く受けない試料による高強度の 測定值が出現するが，影響される測定值も存在すること からワイブル係数はかえって小さくなる．これに対し， $350 \mathrm{mesh}$ ふるい通した泥漿は, 全試料が $44 \mu \mathrm{m}$ 以上の 粗粒子を全く含まないものとなり, 平均強度が高いばか りでなくワイブル係数も大きくなるとして説明される. すなわち，ふるいにより粗粒子を残査として除くことに より粗粒子領域の粒度分布が変わり，除去される残查が 多い場合には，そのふるい目開き径近辺において密な分 布を示し，少ない場合には踈な分布を示す．そしてこの 分布が密なほどワイブル係数は大きくなる．また除去さ れた残查量とワイブル係数の関係は図 9 に示されるよう に良い相関性を示しており，これを裏づけている。

\section{4 長石質原料中のケイ石成分}

本実験で使用した長石質原料（大平長石）は，東濃地 方での陶磁器生産を考慮した工業原料であるが, 既に述 ベたように約 $4 \%$ の石英を含有しており，ふるい残查 にも長石とともに石英を観察している.したがって本実 験結果において顕著な効果を示した極めて微量の $44 \mu \mathrm{m}$ 以上の粗粒子のうち, 実際に影響したのは長石であるか, 石英であるかは, 長石質磁器の強度向上と品質安定化を 一般的に考察するうえで, 明らかにする必要があると思 われる。

これを確認する目的で，上述した $44 \mu \mathrm{m}$ 以上の粗粒 


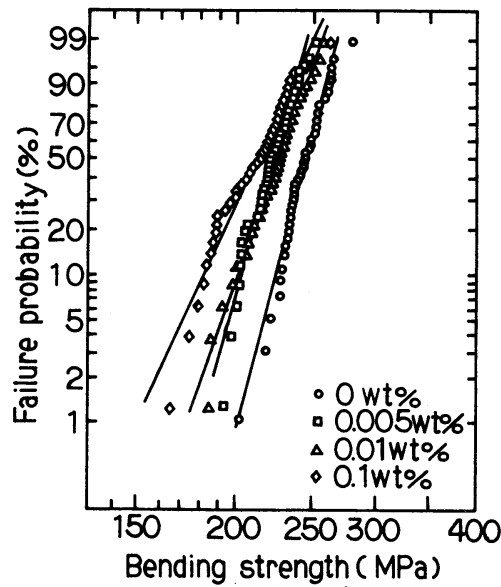

Fig. 10. Effect of coarse feldspar $(44-63 \mu \mathrm{m})$ on Weibull distribution of fired bodies.

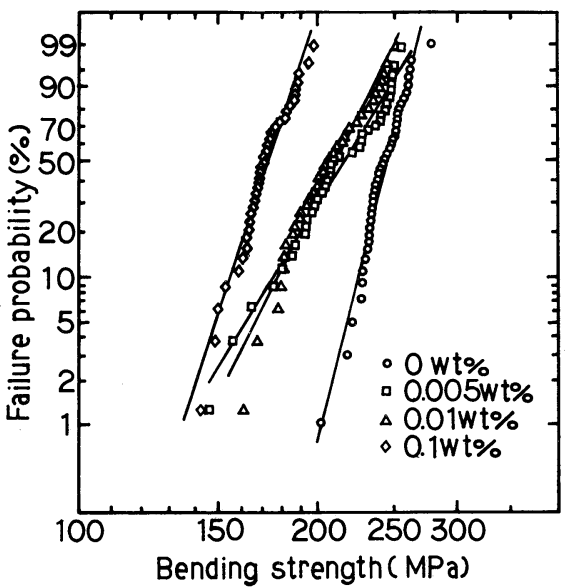

Fig. 11. Effect of coarse quartz $(44-63 \mu \mathrm{m})$ on Weibull distribution of fired bodies.

子を篩別除去した泥漿に対し，44 63 $\mu \mathrm{m}$ の範囲にあ る純度の高い長石又はケイ石を微量の一定量を加え, 同様の強度測定を行った．前者はインド産正長石 $(\mathrm{X}$ 線回折及びノルム計算の結果からケイ石は含んでいな い)，後者はサラワク産ケイ砂 $\left(99.5 \% \mathrm{SiO}_{2}\right)$ を用いた。 測定結果を図 10, 図 11 に示す. 図から明らかなように 長石粗粒子は $1000 \mathrm{ppm}$ 混入しても, 平均強度は低下す るが最高強度部分はあまり低下せず, 結果としてワイブ ル係数が小さくなる. 一方ケイ石粗粒子はわずか 50〜 $100 \mathrm{ppm}$ でワイブル係数を非常に小さくし，1000 ppm ではすべての試料が強度を低下してワイブル係数が再び 大きくなり，本試験での長石質原料の場合に得られた結
果と良く対応している．これらの結果は，長石粗粒子よ りケイ石粗粒子の方が破壊源としての作用が強いことを 示している. すなわち，ケイ石は $44 \mu \mathrm{m}$ 付近で著しく 強度を低下させるのに対し，長石はそれよりいくらか大 きい粗粒子によって同等の効果を生じさせると結論する ことができる.

\section{4. 総 括}

食器として通常の工業生産に適合できるアルミナ強化 磁器素地として， $\alpha$-アルミナ $30 \%$, 長石質原料 $30 \%$, カオリン質原料 $40 \%$ の配合組成比を選び，湿式ボール ミル粉砕の時間及び粉砕後のふるいの目開き径を変えて 調製した泥墏を鋳込み法により成形し， $1350^{\circ} \mathrm{C} に て 1$ 時間還元焼成した種々の角柱状試験片に対し曲げ強度を 測定した。

（1）平均曲げ強度は粉䂶時間の増大とともに大きく なり，粉碎時間とほぼ比例関係にある。

（2）しかし粉研時間の増大とともに強度測定値のワ イブル係数は小さくなる.これは長時間粉砕によっても $44 \mu \mathrm{m}$ 以上の粗粒子が微量残留し，その分布により低強 度試料が発生するからである。

（3）長時間粉砝に対しては，ふるいの目開き径を更 に小さくすれば, 強度増加とともにワイブル係数も大き くすることができる.

（4）混入粗粒子としては長石自体よりも長石質原料 中に含まれる微量のケイ石の効果が大きい.

（5） 24 時間粉砕後，目開き径 $44 \mu \mathrm{m}$ のふるいを通 過させ, $50 \mathrm{ppm}$ 程度の粗粒子を除くことにより，平均 強度 $240 \mathrm{MPa}$ ，ワイブル係数 21 の磁器素地を得ること ができた。

\section{文 献}

1) C. R. Austin, H.Z. Schofield and N. L. Haldy, J. Am. Ceram. Soc., 29, 341-54 (1946).

2) C. J. Allen, Trans. Brit. Ceram. Soc., 63, 77-89 (1964).

3) J. R. Floyd, Ceram. Age, 82, 61-74 (1966).

4) J. R. Floyd, D. V. Royce, Jr. and A. Lippman, Jr., Ceram. Ind., 88, 108-39 (1967).

5) S. I. Warshaw and R. Seider, J. Am. Ceram. Soc., 50, 337-42 (1967)

6) S. K. Khandelwal and R.L. Cook, Am. Ceram. Soc. Bull., 49, 552-26 (1970).

7) A. Dev and R. L. Cook, Ceram. Ind., 98, 24-26 (1972).

8）加瀬滋男, セラミックス, 17, 545-48 (1982).

9）阿部 弘，セラミックス，17，940-50 (1982).

10） R. W. Davidge 著, 鈴木弘茂・井関孝善共訳, “セラミッ クスの強度と破壊”，共立出版 (1982) p. 145.

11）松尾陽太郎, 北上浩一，窯協，93，757-61 (1985). 